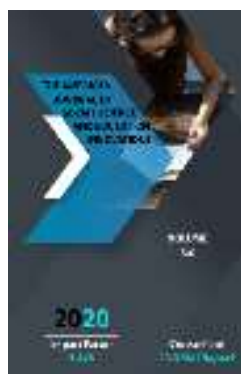

\title{
Plot Construction In A Historical Novel \\ (On The Example Of Nurali Kabul's Novel "The Last Day Of The Sultan Or Amir Sahibkiran And Tokhtamishkhan")
}

\author{
Ganiyev Muhammadamin \\ Teacher Of English Department, Fergana State University, Uzbekistan
}

\begin{abstract}
Journal Website: http://usajournalshub.c om/index,php/tajssei

Copyright: Original content from this work may be used under the terms of the creative commons attributes 4.0 licence.
\end{abstract}

\section{ABSTRACT}

The article reveals how the poetic problems in the historical novel of the talented writer Nurali Kabul were solved on the example of the plot composition. The author relies on the views of such scientists as E. Khalizev, I. Sultan, A. Rahimov, U. Tuychiev as a theoretical basis. The author scientifically substantiated that the plot composition is the basis of the general composition and that it exists as a general system with such types of composition as image composition, narrative composition and content composition.

\section{KEYWORDS}

Plot, prologue, exposition, node, course of events, culmination, solution, epilogue, composition, image, conflict, plot composition, image composition, historical novel.

\section{INTRODUCTION}

At the heart of any historical work lies a major historical event. However, the purpose is to re-tell this or that historical event that took place. This is primarily a system of modern problems. In this sense, a number of issues related to the formation of modern society can be found on the basis of Amir Temur and his system of public administration, socio- political, economic-legal, domestic-individual views. In this sense, through the study of the poetics of historical novels, it is necessary to study such issues as the construction of the state and society in the modern world, the organization of world and human relations, the knowledge of the great spiritual values of our ancestors. 


\section{MATERIAL AND METHODS}

It is known that the core of poetics is the plot composition of the work. As mentioned earlier, the composition of images, the role of artistic speech composition is also unique in the poetics of the work. However, in their relationship, it is advisable to put the event first. This is why most scholars prefer to start with a plot composition when studying an epic work. According to Russian scientist E.Kh. Khalizev: "The word plot refers to the events in a work of art, that is, the whole life of the characters in the chain of changes in time and space, alternating situations and conditions. The events described by the author, together with the characters in the work, form the basis of the world of objects. The plot plays a primary role in the organization of dramatic, epic and lyrical genres "[5, 140]. In fact, in order to know whether a work belongs to a particular genre, first of all, attention is paid to the poetic features of the work, ie the plot, the conflict, the system of images in it, the unity of form and content. Especially in a historical novel, features such as epic scale, weight of content, the presence of several image systems, the multifaceted plot, the sharpness and tension of the conflict are required.

The fact that the plot composition is a key element of the work is well covered in the works of Uzbek theorists. For example, according to academician Izzat Sultan "the event in the novel "plot"... The plot is the interaction of people depicted in the work of art, the contradictions between them, likes or dislikes of each other, in general, the relationship between people is the history, growth, formation of this or that character, type "[3, 108]. Professor U.Tuychiev shared a similar idea: "The plot is the history of the characters, the characters are formed, and the events of the plot are the means of creating the character. The plot has its own elements, and each of them belongs to the perfection of character "[4, 330]. Another literary scholar A. Rakhimov writes that "the plot is a flow of events and emotions in a work of art, the history of the development of characters and conflicts, the full disclosure of the writer's attitude to the events described" $[2,16]$. In "the Dictionary of Literary Criticism", "plot is one of the characteristics of fiction, and the plot is present in all works, regardless of type and genre. However, its manifestation depends in many respects on the type or genre to which it belongs" [7, 287]. In the theories we have cited above, the following aspects of the plot are manifested: 1 ) the plot is the event being narrated; 2) the plot is the character of these people, the flow of their interactions; 3 ) the plot is also a manifestation of the writer's position in the flow of these events; 4) The epic experience, the conflict also belongs to the plot.

\section{RESULTS}

So, the plot formed the basis of the work of art, but this basis consists of different parts, elements. It is divided into prologue (introduction), exposition, node (problem node), course of events, culmination point, solution (conclusion), epilogue (end). These pieces look better and easier in smaller epic genres. But in the epic it is a little more difficult to determine the beginning and end of the parts of the plot. This is primarily explained by the size of the event being described, the width of the image scale, the length of the description.

\section{DISCUSSION}

In particular, Nurali Kabul's novel "The Last Day of the Sultan or Amir Sahibkiran and Tukhtamishkhan" is large and contains a large description of the events, a writer depicts a particular historical event, the place where the event took place, the description of that place, that is, the landscape, a clear portrait of the characters involved in the event, their dynamic character, and even the inner speech of the characters. As a result, the image size expands. In fact, in the artistic perception of 
historical reality, the writer can describe the event he is describing a little more narrowly, based on the reader's ability, but in this case the artistic power of historical reality is lost. Because, no matter how powerful our history is, greatness is formed in the heart of the modern reader. This is how the modernity of the historical novel is seen. In addition, the novel emphasizes the role of spiritual values in the formation of a new society, the understanding of national identity on the basis of historical reality. As a result, the writer used the traditional comparativedescriptive method, that is, the method of showing the best by comparing two realities, events.

In fact, the novel begins with the events of 1391. However, the author does not specify this, but the events within the plot, the speeches of the characters stating that Tukhtamishkhan was enthroned on the throne of the Palace three times give a clear indication of the time elapsed. In addition, it is mentioned in the first chapter that the army stood for three days at the place where it had stopped, and set out again, after walking through Kavrochuk and Sabron, they walked tirelessly through the desert for three weeks, they reached the river Sarıkuzan, which flows into the Sarikupa lake. But the direction in which the huge army marched, and why, set the knot in the plot of the novel. This time, he rides in order to punish Tokhtamishkhan and fight with his army. The writer thus defines historical time and space. Then he proceeds to the main problem that is to compare the image of Amir Temur and Tokhtamishkhan and the structure of the governess their kingdoms. The exposition depicts the amazement of the ambassadors of Tokhtamishkhan, the ruler of the Horde, to compare Amir Temur and his empire with other kingdoms in the world, in particular, the empire of Tokhtamishkhan, in order to show which of them is more glorious. "The ambassadors of Tokhtamishkhan, the ruler of the Horde, have never been so honored in any palace. The value of the gifts given by Timur was several times more than their annual income " $[6,8]$. It is clear from this passage that the ambassadors acknowledge that Timur was superior to Tokhtamishkhan even in giving gifts to the guests. This is one of the subtleties of Timur's diplomacy, and is said to be a way of forming a warm attitude towards himself in the hearts of guests with tolerance and sincerity. This warmth is aimed at easing Tokhtamishkhan's hostile policy towards Amir Temur in the first dialogue after the exposition. This is where the first bud of the knot in the novel appears. In fact, the title and presentation of this novel is partially felt, but now it is clearly said here: "Tell Hazrat Khan openly that fighting the army of Timur, the horde of Turan is not easy in any situation. Otherwise, we will have problems in the morning, "Oloman Tumat said to Abruybek Karakirgiz. - Explain that Emir Amir ul umaro Alibek's coming and apologizing to the khan is the only way to prevent the tragedy. Otherwise, the country, that never seen a bigger war than the fight of princes for the throne until now, will be collapsed, - said Kara-Kirgiz"[6, 8].

It is clear from the passage that there is a disagreement between Sahibkiran Temur and Tukhtamishkhan, and that a representative of Tukhtamishkhan (the prime minister is asked here) would come and apologize on behalf of the khan, and hence the war and its aftermath in the country would be disrupted. But the question is whether the khan will agree to this, and the first plot in the novel is clearly expressed in this way. "In the creation of any historical work, the writer relies on two sources. The first source is undoubtedly historical memoirs; the second is a person who has seen or heard memories of historical periods and historical figures from their ancestors" $[1,68]$. In fact, as our scholar Nurali Kabul pointed out, he revealed the plot carefully studying the historical-memoir sources and the causes of the great war between Amir Temur and Tukhtamishkhan, 
the Turan state and the Golden Horde. As a result, the plot composition began to be sharp and tense. There is seen a conflict between the two sides. Hence, the conflict in the novel is also explicitly described from the point at which the knot was released. However, this description is based on the requirements of the novel genre and begins to be presented in detail and on a large scale. That is, when the first part of the knot appears, its weight, the effect of the knot on the subsequent development of plot events, can be quickly understood by the discerning reader. To this end, the author goes into detail about the system of problems posed and who reacted to preventing the problem from occurring. As a result, the plot line includes people who lived in history under the name of Idiku Mangit (Karakalpak national hero Ediku biy, in Karakalpak folklore there is a folk epic named after him - M.G.), Temur Kutlug, Kuncha oglon.

These events serve to prepare the reader for the meeting of the main protagonists of the novel Sahibkiran Temur and Tokhtamishkhan, to teach a deeper understanding of the major conflict in the novel. In doing so, the writer, based on his artistic intent, takes events that are considered the most important in history. That is, the fact that the ambassadors were taken to Sahibkiran Temur and treated warmly is an important part of the description of the historical event, but their meeting with a group of compatriots led by Idiku Mangit at the residence of Amir Temur is a image created by the writer. Because it was natural for Idikubek, Temur Kutlug, Kuncha, who escaped from The khan of the Golden Horde and his pressure and came here, to know that the ambassadors of Tokhtamishkhan were there and to meet them, and the author uses a vivid description of this situation to intensify the conflict on both sides, which deepened the effectiveness of the novel's semantic composition. On the other hand, these images serve to show how large the scale of the expected plot events is by forming a twosided system of contrasting image composition in the novel. Thus, the writer was able to assign more than one artistic and aesthetic task to every detail, image or other element of the plot in the novel. In particular, it is described that Korakirgiz as a head ambassador went to Temur Kutlug's banquet at his horde by his invitation and was afraid of it. At this point, the right question arises as to why they should be afraid, because Temur Kutluk, Idiku Mangit are citizens of their compatriot - the Golden Horde. But there is a delicate political game involved. Temur Kutlug and Idiku Mangitbek opposed Tokhtamish and fled from him and took refuge in Amir Temur's horde. Secondly, it is important for them to know the situation in Sarai Berka, the capital of the Golden Horde, and how attitudes towards them are changing. Thirdly, the parties were well aware that the detention of Ambassador Karakyrgyz without being allowed to leave was necessary for Amir Temur to know what the next course of Tokhtamishkhan's policy would be and to take the next step accordingly. Placing these people in almost the same situation and status around the same table was a great tool for the writer to convey that several khans of the Golden Horde throne after Orishan had reached the height of internal chaos in the country as a result of a mutual throne dispute. In contrast, there are indications that the principle of building a strong centralized state in the country of Turan has been consistently implemented. For example, if giving ambassadors more than the income of one's own country indicates that one is in a rich and prosperous country, the fact that political refugees from other countries, particularly Timur Kutlug and Idiku Mangit, took refuge in Timur's kingdom, suggests that the country is more powerful than the Golden Horde and that the Golden Horde cannot solicit and punish them politically. Hence, the plot of the novel develops mainly on the basis of the 
image of such internal struggles of the two sides.

The image of Amir Temur in the course of events is described for the first time below:

"The army is on its way. The commander-inchief rides pensively, saddling his horse. Ever since he has attained consciousness and gone out to the crowd of people, he is faced with great happiness or unhappiness. The blessing of the Almighty was that luck did not turn away from him. The Lord of the universe did not spare him out of compassion. Those who avenged him faced failure, and the fortunes of his friends and benefactors were favorable. Allah raised his respect and dignity in the presence of those who followed him. When he asked the Almighty for little, the Almighty rewarded him with many. Allah bless him from now on. Let him lighten his face in the presence of friends and foes!" [6, 11].

The writer portrays Amir Temur's movement in a portrait style and gives his inner monologue. It shows that the Sahibkiran analyzed his activities, that his heart was filled with gratitude to the Creator, and that his intentions were still great. With the help of a portrait and an internal monologue, the plot depicts the real character from the inside and outside. Here it is revealed that the plot and artistic description are used to create realistic scenes of life, based on the big and small events in the plot, the movements and actions of the characters, their thoughts, creating a unique internal content structure. When the writer introduces the image of Amir Temur into this part of the plot, he does not forget that there is a huge army behind him, and huge unexplored places await him. The commander at the head of the army and his command of a large army on a large field associatively awakens a variety of knowledge and skills in the student and brings the plot to life.
As the writer slowly develops the plot, he skillfully adds to it the artistic speech of the composition, such as images, portraits, descriptions, landscapes of descriptive expression. As a result, the relationship between the plot and other elements of the composition is resolved politely and skillfully. They complement each other and enhance the art of the novel. This, in turn, ensures that the composition of the plot, the composition of images and the composition of the expression, as a whole, acquires a holistic artistic and ideological content, and the unity of form and content is perfect.

\section{REFERENCES}

1. Karimov N. Three great sims. Literary studies and articles. - Tashkent: Mumtoz soz, 2019. - 428 p.

2. Rahimov A. Roman art. - Fergana: Fergana, 2015. - 96 p.

3. Sultan, Izzat. Literary theory. Tashkent: Teacher, 2005. - 256 p.

4. Toychiev U. Criteria of art in Uzbek literature and their rhythms. Tashkent: Yangi asr avlodi, 2011. - 508 p.

5. Khalizev Theory of Literature. Moscow: Higher school, 1999 .- 392p.

6. Kabul, Nurali. The last day of the Sultan or Amir Sahibkiran and Tokhtamishkhan. - Tashkent: Kamalak, 2014. - 576 p.

7. Kuronov D., Mamajonov Z., Sheralieva M. Dictionary of Literary Studies. - Tashkent: Akademnashr, 2010. - $400 \mathrm{p}$. 